\section{Impressões sobre América Latina}

Maria Teresa de Oliveira *

Inicialmente, gostariamos que falasse um pouco sobre sua experiência no Brasil.

Estive no Brasil, antes, uma vez, para fazer uma pesquisa sobre a História do Movimento Operário Brasileiro. Esse foi 0 assunto da minha tese de Doutorado, especialmente a Política do Movimento Operário no Brasil de 1930 a 64. Fiz a pesquisa aqui, de 60 até 62 , ficando mais de dois anos no Brasil. Escrevi um livro sobre esse assunto e agora gostaria de publicá-lo no Brasil, em português. Nos Estados Unidos, ensino no Departamento de História, da Universidade Esta. dual da Califórnia, em Los Angeles, e também no Departa. mento de Estudos Latino-Americanos. Ensino História do Brasil e da América Latina, em geral, tendo me especializado na época contemporânea. Depois dessa sobre o Brasil, fiz pesquisas em Cuba, um estudo global da Revolução Cubana até 1976, um estudo da reforma agrária no Chile, na época de Allende. Fiz também vários estudos sobre o México, estudos sobre a relação existente entre os movi. mentos operários nos Estados Unidos e América Latina e a influência da atuação do governo dos Estados Unidos na. América Latina. Agora estou concentrando minhas pes. quisas sobre a política dos Estados Unidos na América Central.

Por que se tornou uma especialista em assuntos latinoamericanos?

Isso é uma escolha pessoal, poderia dizer psicológica. Não sei como a gente faz essas coisas. Talvez por acidente. Meu pai, durante a primeira parte da Segunda Guerra Mundial, trabalhou na política externa dos Estados Unidos e veio ao Brasil. Ele me contava essas histórias do que fazia. Ainda antes, em 1933, ele veio pilotando um pequeno avião para América do Sul, numa viagem muito perigosa. Chegou a muitos parses, foi à Argentina, veio ao Brasil. Caiu no Amazonas e foi encontrado. Ele tinha, como se diz, a aventura nas veias. $\mathrm{Na}$ Universidade, eu tinha de escolher uma especialização e, como tinha ido várias vezes ao México, falava espanhol e gostava de História, fiz uma ligação entre as duas coisas. Como já dominava o espanhol, teria uma razão para estudar o português. Ganhei uma bolsa para estudar português, quando estava fazendo minha especialização e, depois disso, escolhi um tema que me trouxesse ao Brasil para usar Cadernos de Saúde Pública, R.J., 2(2):247-250, abr/jun, 1986
REGISTRO

Entrevista com Timothy Harding julho 3, 1986 - 14:00/15:00 horas

*Coordenadora do PECe Professora do Departamento de Ciências Sociais. 
o português que tinha aprendido. Fiz meu Doutorado em Stanford, onde estive em contato com os intelectuais jovens, radicalizados pelos seus estudos de América Latina. Quando vim para o Brasil, a Revolução Cubana parecia dizer que já não era a classe operária a classe revolucionária, mas sim os camponeses e a classe média. Eu queria ver se isso não era um mito, e por isso decidi estudar o movimento operário.

Além do México e de Cuba, você esteve também no Chile .

No Chile, na Bolívia, em quase todos os países da América Latina, menos o Paraguai, e em quase toda a América Central. Antes de fazer meus estudos para o mestrado, estudei História no México por dois anos, na Universidade do México.

Você poderia comentar o curso que veio dar na Escola Nacional de Saúde Pública?

Fui convidado pelo Departamento de Ciências Sociais. Houve uma negociação que durou vários meses sobre o que seria o tema do curso que eu viria dar. Eu queria escolher um assunto que fosse útil para o grupo daqui, que se está especializando em Saúde Pública, mas que também estivesse ligado às pesquisas que eu fazia. Escolhemos afinal um Seminário sobre Desenvolvimento e Subdesenvolvimento na América Latina, focalizando as implicações para o setor público. Vamos começar estudando a relação entre a presença das multinacionais no Brasil e as implicações sobre o capital nacional no Brasil. Baseei-me num estudo concreto, uma pesquisa que fiz, e nos estudos de Peter Evans que é professor de Ciências Políticas na Universidade da California. Ele é, também, um conhecedor da América Latina. Estou usando como texto básico o seu livro $A$ Triplice Aliança. Ele publicou a idéia central do seu trabalho na revista Latin American Perspectives. Sou um dos fundadores dessa publicação e acompanhei o desenvolvimento das idéias de Evans. Vamos nos concentrar, na primeira parte do curso, nesse trabalho concreto, onde ele dá exemplos de várias indústrias, a petroquímica, a farmacêutica, a indústria textil e outras. Vamos, também, fazer comparações entre as experiências do México e do Brasil, focaliżando este problema dos três capitais: privado, estatal e multinacional. Mostraremos, ainda, o contraste com a experiência na Nicarágua e de Cuba, países onde a Revolução impossibilitou a mesma ação das multinacionais, ainda que esses países tenham tido economias completamente diferentes, antes da Revolução. Na última parte do curso, falaremos da política social no Brasil, em comparação, outra vez, com o México, a Bolívia e Cuba, incluindo as despesas do Estado no setor de Previdência Social. Os estudantes do Seminário vão escolher temas ligados às idéias centrais do curso, mas tamberm ao tipo de pesquisa que lhes interessam. 
Acho que vai ter muitos resultados positivos. Creio que é uma necessidade ligar o estudo desses problemas de depen. dência com as lutas sociais concretas num paŕs. Por exemplo, no seu estudo Evans admite que existe uma luta social, mas, ao longo do livro, ele só fala das lutas entre capitais, como se não houvesse uma luta popular definindo o contexto social. Os teóricos que estudam o capital, como Fernando Henrique Cardoso, em geral têm uma idéia muito pessimista sobre as possibilidades das lutas das classes oprimidas. A literatura da Dependência quase elimina a luta de classes, até considerar parte da classe operária como aliada do imperia. lismo. Acho isso completamente errado. Quero tentar, no Seminário, levar a discussão desses problemas, desenvolvendo a idéia de como as lutas sociais determinam os fenômenos que são considerados como Dependência. Por outro lado, eu acho que muitos estudos teóricos sobre a Dependência não entram nos detalhes das indústrias onde isso acontece. Os estudos que os participantes deste Seminário vão fazer giraraão em torno de análises concretas, completados com a discussão teórica. Vamos fazer o possível para estabelecer a relação entre a luta dos trabalhadores e o desenvolvimento técnico e financeiro do capital e vincular isso à política do Estado. Acredito que isso vai esclarecer o processo que todos conhecem em geral, mas ninguém entende especificamente. A originalidade do curso é abordar as implicações da ação dos diferentes capitais para uma política social do Estado, refletindo não só a crise que o Estado sofre, mas também as exigências do povo quanto à assistência social, como os governos respondem a isso, governos que em geral sofrem uma falta de recursos e têm de escolher se vão subvencionar as multinacionais ou se vão atender às necessidades popula. res. Outro resultado é que os estudantes daqui vão conhecer melhor os estudos de pensadores norte-americanos. Estou escolhendo pontos que reflitam a pesquisa progressista que se está fazendo nos Estados Unidos e que talvez seja desconhecida aqui.

Outro resultado, para mim, vai ser a troca de idéias $e$ a dis. cussão, da qual espero poder ver melhor o pensamento brasileiro. Isso terá uma grande repercussão para a minha própria pesquisa. Também estou acompanhando vários grupos de pesquisa, fora da sala de aula. Vou participar de seminários e grupos de trabalho que estão estudando a par. ticipação nas comunidades perto da escola. Então poderei apreciar a organização interna que estas comunidades têm. Na América Latina, os problemas sociais se refletem nesse surgimento de movimentos sociais, afora do movimento sindicai. No México, por exemplo, o movimento operário se enfraqueceu muito, em parte pelo controle estatal e em 
parte como resultado do recesso econômico. Mas as lutas populares de bairro, entre camponeses, etc, estão tomando uma força maior. A revolução na Nicarágua foi dirigida por um movimento com forte participação da juventude, expulsa da força de trabalho pelo tipo de desenvolvimento."

$O$ que pensa desse progràma da Escola Nacional de Saúde Pública trazer professores visitantes?

Sou o primeiro bolsista de uma série no Departamento de Ciências Sociais. Quero que a experiência seja boa. Já está começando muito bem. Acho que vai ser muito proveitoso

Edição: para a Escola e mais ainda para os futuros bolsistas que Maria Teresa de Oliveira vierem. 